Jayapangus Press Jurnal Penelitian Agama Hindu Terakreditasi Peringkat 2
Volume 5 Nomor 2 (2021)

ISSN : 2579-9843 (Media Online)

http://jayapanguspress.penerbit.org/index.php/JPAH

\title{
BIAS GENDER KAPAMANGKUAN DI DESA MENGESTA KECAMATAN PENEBEL KABUPATEN TABANAN
}

\author{
I Wayan Wastawa ${ }^{1}$, I Wayan Suwadnyana ${ }^{2}$ \\ ${ }^{12}$ Universitas Hindu Negeri I Gusti Bagus Sugriwa Denpasar \\ 1balivas65@gmail.com, 2suwadnyanaiwayan@gmail.com
}

\begin{abstract}
The analysis of the kapamangkuan gender bias in Mengesta village is a socio-cultural study of the imbalance of rights and obligations between pamangku lanang and pamangku istri. This study uses a qualitative methodology, data collection were done through observations, literature study, and in-depth interviews with 7 traditional and religious leaders as informants. The present study concludes that the procedures for pamangku candidates' coronation were as follows: selection, lineage, nyanjan ceremony, and distribution of lekesan. Gender inequality exists due to several factors, namely: the purusa and pradana system in Balinese culture; 2) male dominance in kapamangkuan; 3) kapamangkuan education prioritizes pamangku lanang; 4) The labeling of pamangku istri with their domestic duties as ceremonial amenities maker, and 5) menstrual cycle myths factors. Furthermore, the gender identification in kapamangkuan in Mengesta village are as follows: 1) The labeling of pamangku istri as the socialization of women into gender polarity; 2) the kapamangkuan education system based on biological differentiation, 3) a second marriage system that is considered unholy, 4) through unclear patterns of pamangku istri's clothing, and 5) Gender identification through adat (local social system). In general, there is still injustice to pamangku istri regarding her rights and obligations despite her equal position as a pamangku.
\end{abstract}

\section{Keyword : Gender Bias, Pamangku, Kapamangkuan}

\begin{abstract}
Abstrak
Analisa bias gender kapamangkuan di Desa Mengesta merupakan analisa sosial budaya terhadap fenomena ketimpangan hak dan kewajiban antara pamangku lanang dengan pamangku istri. Penelitian ini menggunakan metodologi kualitatif, pengumpulan data berdasarkan obervasi, studi kepustakaan dan wawancara mendalam dengan 7 orang informan tokoh adat dan agama. Penelitian disimpulkan, tata cara penobatan calon pamangku melalui: pemilihan, keturunan, upacara nyanjan, dan pembagian lekesan. Faktor-faktor ketidakadilan gender dalam kapangkuan karena adanya: sistem purusa dan pradana dalam budaya Bali; 2) dominasi laki-laki dalam kapamangkuan; 3) pendidikan kapamangkuan megutamakan pamangku lanang; 4) pelabelan pamangku istri dengan tugas domestiknya sebagai pembuat upakara; dan 5) faktor mitos menstruasi. Sedangkan penggenderan kapamangkuan di desa Mengesta, yaitu: 1) pemberian label pamangku istri sebagai sosialisasi wanita ke dalam polaritas gender; 2) sistem pendidikan kapamangkuan melalui pembedaan biologis, 3) sistem perkawinan kedua yang dianggap tidak suci, 4) melalui pola pakaian pamangku istri yang tidak jelas, dan 5) penggenderan melalui adat. Secara umum masih ada ketidakadilan kepada pamangku istri terhadap hak dan kewajiban kapamangkuan-nya dalam posisi yang sama sebagai pamangku.
\end{abstract}

Kata Kunci : Bias Gender; Pamangku; Kapamangkuan. 


\section{Pendahuluan}

Secara umum berlaku di Desa Mengesta yang diangkat menjadi pamangku adalah dari garis purusa (laki-laki), sesuai dengan sistem patrilineal. Penobatan Pamangku di Desa Mengesta, adalah bagi mereka yang telah berkeluarga, sehingga pada saat pelaksanaan upacara pawintenannya kedua orang bersuami istri itu dilakukan secara bersama-sama, dan lumbrah dipanggil dengan pamangku lanang dan pamangku istri. Peristiwa seperti ini hanyalah sebagai usaha pelabelan kedudukan saja, sehingga kelihatannya peran gender terpenuhi. Dengan demikian ideologi yang mempengaruhi pengkontruksian gender di Desa Mengesta adalah ideologi patriarki atau budaya patriarchal menurut istilah Bawa Atmaja(Bawa Atmadja, 2004:63).

Pengklasifikasian manusia atas jenis kelamin dikuatkan oleh kitab Sarasamusccaya, 435, yang memunculkan ketidakadilan gender yang menempatkan dan pelabelan perempuan sebagai makhluk yang lemah, bencana dan kerusakan dilabelkan karena perbuatan oleh perempuan. Menurut Sumbullah (2008):, dinyatakan "perempuan sebagai penghancur kebijaksanaan, perempuan sebagai sumber malapetaka, diposisikan sebagai makhluk yang lemah secara fisik dan intelektualitas, sehingga mobilitasnya terbatas untuk menjadi pemimpin" (xviii). Perempuan Bali Secara kasat mata memperoleh kesetaraan gendernya yang memikul beban ganda sebagai ibu rumah tangga dan pekerja keras diluar kodratnya dengan etos kerja yang tinggi. Sexual differentiation akibat adanya pengenderan terhadap posisi lakilaki dan perempuan dengan pekerjan yang beroposisi domestic-publik, serta struktur inferioritas-superioritas kehidupan sosialnya. Superioritas (laki-laki) juga muncul pada posisi penobatan pamangku di Desa Mengesta, karena menganggap posisi perempuan sangat lemah secara fisik maupun intelektualitasnya. Di samping posisi sebagai pamangku dikaitkan kesucian. Secara fisik perempuan dalam posisi ini dilemahkan kesuciannya secara lahir melalui mitos menstruasi yang mengganggu aktivitasnya.

Merujuk pendapat Delaney dalam Abdullah (2006:215) dalam hubungan dengan kapangkuan juga terkait dengan mitosmestruasi yang dianggap kotor, kutukan Tuhan sebagai tanda dari inferioritas perempuan yang juga dapat dikatakan mengganggu keteraturan social. Perempuan dalam kondisi mentruasi dalam kehidupan social keagamaan masyarakat Hindu tidak diperkenankannya untuk hadir di lingkungan tempat suci (pura) dan mengerjakan sarana upacara (banten) yang dianggap mengganggu kesakralan dan kesucian.

Dibalik stereotipe dan subordinasi terhadap pelabelan negative perempuan Bali dalam pengangkatan pamangku istri di desa Mengesta, fenomena yang terjadi, bahwa penobatan pamangku dilakukan secara bersama-sama antara suami dengan istrinya, yang selanjutnya menyandang gelar pamangku lanang dan pamangku istri. Tetapi, pada kenyataannya pamangku istri karena inferioritas sebagai pendamping suami tetap mengambil pekerjaan domestik dalam kepamangkuan yaitu tukang banten (pembuat sarana upacara). Tidak mendapat kedudukan dan peran yang setara dari pamangku lanang. Itu mungkin kelihatan suatu kewajaran ketika pamangku lanang masih hidup. Apabila, pamangku istri telah meninggal dunia itu tidak menimbulkan suatu persoalan bagi pamangku lanang dalam menjalankan kewajibannya sebagai pamangku, karena masih banyak yang bisa mengerjakan segala perlengkapan upacara. Tetapi apabila pamangku lanang meninggal dunia terlebih dahulu, secara psikologis terjadi ketimpangan dalam pelaksanaan kewajiban oleh pamangku istri yang menimbulkan masalah sosial keagamaan. Hal ini disebabkan oleh pelabelan negative terhadap perempuan sebagai seorang pamangku. Atau, ada kepentingan di balik itu, agar masyarakat tidak memberikan hak atas kewajibannya nanti setelah ia meninggal, ataukah masyarakat menginginkan pamangku yang usianya lebih muda dan sehat untuk melakukan kewajiban kepamangkuan-nya. Permasalahannya, kedudukan pamangku istri adalah sama dengan pamangku lanang sebagai pamangku, di samping pendidikan keagamaan dimungkinkannya seorang perempuan menjadi seorang pamangku sehingga paradigma pelabelan wanita secara negative dapat dihindari, dan dapat melanjutkan kewajiban suaminya sebagai pamangku. 
Penelitian ini ditunjang dari hasil penelitian yang sebidang, akan tetapi tidak ada yang membahas mengenai gender kepamangkuan. Arniati (2004) dalam penelitiannya "Gender dan Tokoh Wanita Spiritual Analisis Pengenderan Atas Smerti”. Menjelaskan bahwa, ajaran luhur setiap kitab suci seharus mencerahkan, membebaskan, menjunjung tinggi keadilan dan ketentraman. Tetapi kenyataannya, kitab suci sangat tergantung pada person (orang) dan kultur (budaya). Sehingga menimbulkan penafsiran, yang berakibat agama dijadikan dalil untuk melanggengkan konsep patriaki dan juga dijadikan legitimasi kekerasan terhadap perempuan serta sarat dengan ketidaksetaraan gender. penafsiran tentang pengenderan pada kitab Manawadharmasastra dan Itihasa. Akan tetapi dalam Itihasa (Ramayana dan Mahabharata) terdapat penggambaran wanita sebagai panutan spiritual. Mulia (2008) dalam penelitian "Gender dalam Perspektif Teks Sarasamuscaya" menguraikan bahwa permasalahan gender terjadi sebagai akibat sistem budaya patriarki yang dianut oleh masyarakat. Budaya ini mengakibatkan kaum perempuan tidak memiliki kesempatan sosial yang sama di masyarakat. Mereka menjadi kelas dua yang harus mengikuti pihak laki-laki. Hasil temuannya, menyimpulkan bahwa dalam teks Sarasamuscaya mengandung wacana gender yang cukup siginifikan, dimana perempuan dinyatakan sebagai sumber penderitaan dan segala sesuatu yang jelek sebagai pelabelan negative. Tetapi di sisi lain Sarasamuscaya menguraikan bahwa seorang ibu adalah yang paling mulia di antara manusia.

Pandangan teks Sarasamuscaya yang diinterpretasi oleh Mulia di atas, merupakan jalan untuk lebih mendalami gender terhadap perempuan Bali yang mengambil jalan pada profesi pamangku di Desa Mengesta. Apakah pandangan masyarakat terhadap pamangku perempuan sebagai manusia kelas dua, padahal dalam penobatannya sebagai pamangku sama-sama menduduki status kepamangkuan-nya.

\section{Metode}

Artikel ini disusun berdasarkan hasil penelitian jenis kualitatif dengan pendekatan emic terhadap fenomena budaya menurut masyarakat di Desa Mengesta. Data penelitian lebih dominan dikumpulan dari data primer bersunber dari 10 orang informan dari para tokoh agama dan masyarakat adat setempat melalui teknik observasi dan wawancara. Sedangkan data skunder diperoleh dari beberapa literature sebagai pendukung data primer. Untuk menganalisis data penelitian dipergunakan paradigma klasik dan Post-feminisme yakni teori struktural fungsional, teori ketimpangan gender, dan teori gender yang menekankan pada interpretasi, persepsi dan pemahaman masyarakat terhadap gender kapamangkuan, faktor-faktor ketidakadilan dan upaya-upaya pengenderannya yang diimplementasikan dalam aktivitas sosial-budaya dan keagamaan masyarakat di Desa Mengesta.

\section{Hasil dan Pembahasan}

\section{Sistem Pemilihan Pamangku di Desa Mengesta}

Pamangku adalah orang suci umat Hindu dengan tingkat upacara penobatannya ekajati yang dapat dikelompokkan pada status pinandita. Kata pamangku mendapat awalan " $k a$ " sebagai kata sifat dan akhiran "an" menjadi kapamangkuan yang berarti sifat yang melekat pada pamangku terhadap fungsi, peran hak dan kewajibannya atas status sosial pamangku yang disandangnya dalam kehidupan masyarakat Hindu di Bali. Di Bali status rohaniawan dilihat dari tingkat upacara penobatannya dapat dibedakan menjadi dua tingkatan, yaitu 1) Upacara madiksa ditujukan kepada rohaniawan yang tergolong dwijati, selanjutnya disebut sulinggih dengan sebutan nama, Pedanda, Empu, Dukuh, Resi dan sejenisnya. 2) Upacara Pawintenan ditujukan kepada rohaniawan yang tergolong ekajati atau "walaka", selanjutnya memperoleh gelar nama: Pamangku, Dukun, Pinandita, Balian, Mangku Dalang dan sejenisnya. Fungsi, peran, hak dan kewajiban pamangku disesuaikan dengan kedudukannya sesuai dengan sasana pamangku. Untuk itu dalam konsep kapamangkuan dalam penelitian ini menganalisa mengenai penyimpangan pemahaman oleh masyarakat atas fungsi, peran, hak dan kewajibannya dalam 
hubungan dengan gender dalam status sosial keagamaan pamangku di desa Mengesta, Kecamatan Penebel Tabanan.

Sesuai dengan falsafah sosial desa mawacara pada masyarakat Bali, bahwa setiap aktivitas sosial keagamaan disesuai dengan tempat, waktu dan keadaan dimana aktivitas itu berlangsung. Demikian pula dalam hubungannya dengan pemilihan seorang pamangku tidak serta merta didasarkan pada sastra belaka melainkan disesuaikan pula dengan tradisi setempat (kuna dresta). Pada umumnya memilih pamangku sebagai orang yang disucikan di desa adat di Bali adalah mengikuti beberapa tahapan:

a. Melalui prosesi upacara nyanjan, yaitu dengan meminjam tubuh seseorang yang dianggap dimasuki para Dewa dengan posisi sedang kerawuhan. (Sarad No.10/2000, dalam Suhardana, 2006:11-12)

b. Penggunaan kawangen (sarana upacara sebagai simbul Tuhan) yang diberikan kepada beberapa orang calon pamangku yang dianggap memenuhi syarat sebagai pamangku dan sebelumnya telah ditetapkan oleh masyarakat pangempon pura. Satu kwangen diberikan kepada satu orang calon pamangku. Salah satu kawangen yang dibagikan kepada calon pamangku bertuliskan rerajahan Ongkara, selanjutnya tersebut sebagai sarana untuk memuja Dewa yang berstana di Pura dimana upacara dilaksanakan. Setelah dilaksanakannya pemujaan, maka kawangen tersebut diminta kembali oleh panitia pelaksana upacara, selanjutnya dibuka serta disaksikan oleh seluruh masyarakat. Calon pamangku yang memperoleh kawangen bertuliskan rerajahan Ongkara terpilih sebagai pamangku.

c. Pemilihan pamangku berdasarkan keturunan. Mereka yang merupakan keturunan pamangku yang memiliki etika dan moral yang baik dapat dipilih sebagai pamangku.

d. Pamangku dipilih secara demokratis atas dasar suara pemilih terbanyak dari anggota $\mathrm{krama} /$ masyarakat yang berhak memilih dan yang berhak dipilih.

Di desa Mengesta masih mempergunakan ke empat tata cara pemilihan pamangku di atas, yakni yang pertama dilakukan adalah dengan memperhatikan keturunan anak laki-laki tertua atau yang termuda dari keluarga pamangku; kedua dengan melakukan Nyanjan apabila tidak adanya dari keturunan pamangku; ketiga melalui pemberian lekesan, dan keempat baru dengan pemilihan secara langsung oleh kerama desa adat. Menurut Pamangku Pura Puseh Desa Adat Wongaya Betan, pada saat pemilihan pamangku di Pura Panti Natar Sari Desa adat Wongaya Betan, bahwa pamangku yang telah meninggal mempunyai (8) keturunan dalam status purusa (laki-laki) dan dua (2) keturunan yang berstaus pradana (perempuan). Kedelapan keturunan pamangku itu menyatakan siap untuk ngayah di Pura Panti sebagai pamangku. Pengempon Pura Panti ada yang menginginkan anak paling tua ditunjuk sebagai pamangku, ada menginginkan anak yang paling muda, dan sebagian lagi masyarakat menginginkan diantara keturunan pamangku yang memiliki pengetahuan agama. Dengan adanya perbedaan pendapat tersebut, maka kedelapan keturunan pamangku sepenuhnya menyerahkan kepada pihak kerama pura dan pamangku untuk melakukan upacara Nyanjan. Hasil yang dicapai dalam upacara Nyanjan ternyata berbeda dengan apa yang diinginkan oleh kerama pengempon pura, ternyata yang mendapat restu adalah anak kembar yang ke tujuh (7) dan ke delapan (8), keduanya berhak menjadi pamangku walaupun status kewajibannya berbeda. Saudara kembar yang lebih muda memikul kewajiban sebagai pamangku utama di Pura Panti sedangkan yang lebih tua sebagai pamangku pangabih (I Nengah Suwita, wawancara tanggal 19 Maret 2019).

Berdasarkan keterengan informan di atas, maka pemilihan pamangku dengan tradisi nyanjan meruntuhkan tata cara pamangku melalui keturunan, yang mana yang harusnya terpilih adalah keturunan anak tertua atau anak yang termuda, malahan yang terpilih melalui upacara nyanjan adalah keturunan anak kembar yang ke tujuh dan ke delapan. Hal ini terjadi, karena dipercaya bahwa anak kembar ini telah dinobatkan pada saat kelahiran atas kehendak Ida Sang Hyang Widhi Wasa. 


\section{Ketidakadilan Gender Dalam Kapamangkuan di Desa Mengesta a. Faktor Sistem Purusa dan Pradana dalam Budaya Bali}

Teori ketimpangan gender dari Ritzer (2005:420), maka ketimpangan gender merupakan teori yang melihat secara holistik faktor-foktor tentang ketidak adilan gender kapamangkuan. Teori ini berlandaskan pada empat oposisi biner yang menandai empat ketimpangan gender kapamangkuan di desa Mengesta. Teori ini melihat, pamangku lanang dan pamangku istri diposisikan secara berbeda di dalam masyarakat adat, sehingga ada ketimpangan secara spesifik. Pamangku istri memperoleh status sosial, hak dan peluang untuk mengaktualisasikan diri lebih rendah dari pamangku lanang yang memperoleh posisi sosialnya berdasarkan pendidikan, keturunan dalam sisten patriarki dani atau berdasarkan faktor-faktor penting lainnya.

Purusa dan pradana memiliki banyak arti dan makna. Purusa di suatu tempat bisa diartikan immaterial, dalam tempat lain positif, berani, laki-laki, aktif, giat bahkan ada kalanya berarti Sanghyang Widhi. Sedangkan Pradana mengandung makna kebalikan dari apa yang tersebut di depan, yakni: material, negatif, nrimo, wanita, pasif dan sebagainya (Kaler, 1994:121). Sistem kapurusan di Bali, adalah akibat menentukan suatu kewajiban untuk meneruskan garis keturunan, menentukan status keturunan, menentukan kewajiban pemeliharaan orang tua sampai dengan upacara kematiannya, dan menentukan kewajiban untuk memeliharan serta memuja rohk leluhur di sanggah kawitannya. Hal ini dimaksudkan untuk menjaga tata tertib hubungan kekeluargaan terhadap status seseorang dalam ikatan kekerabatan, mana yang boleh dan tidak boleh dilakukan. Pertalian keluarga ini adalah sebagai pengikat siapa boleh melakukan perkawinan dengan siapa, siapa boleh melanjutkan garis keturunan di keluarga mana, siapa boleh mewaris dan atas warisan siapa, dan siapa boleh melakukan sembah di tempat suci (kawitan).

Penentuan kedudukan secara biologis tidaklah cukup dalam hukum adat di Bali, melainkan kedudukan secara agama juga memegang peranan yang sangat dominan. Karena dalam suatu perkawinan dilihat dari sahnya perkawinan ibu dengan ayahnya menurut syarat agama. Manawa Dharmasastra I.11 ada dijelaskan, bahwa "menyembah Hyang Widhi merupakan salah satu dari swadharma umat. Bersamaan dengan itu, memuja leluhur yang bersumber dari "cikal-bakal yang kekal (Purusa)-pun merupakan dharma yang pelik pula. Karena itu, bagi setiap orang hendaklah diusahakan untuk secara pasti ditentukan garisleluhurnya yang bersifat Purusa (kebapaan), hingga dengan itu dapatlah nanti ia melaksanakan swadharmanya sebagai umat dan keturunan dari seseorang sekaligus". Swadharma dalam memuja leluhur Purusa dpt dalam bentuk:

1) Guru susrusa (loyal kepada leluhur) dikala leluhur masih hidup

2) Pitra yadnya (mengupacarai jenazah leluhur) dikala leluhur masih bersawa ataupun jiwanya masih dalam wujud pitra;

3) Pitra puja (menyembah jiwa leluhur setelah upacara Pitra yadnya) setelah leluhur berstatus selaku Bhatara-Bhatari di Pamrajan, Pura Dadia, Dharma, Ibu, Kawitan dan sebagainya (Kaler, 1994:123).

Demi terlaksananya swadharma agama, maka dalam masyarakat ditetapkan ketentuan ikatan, kedudukan dan garis kekeluargaan yang berdasar kapurusan (laki-laki), lawannya Pradana yang merupakan pelengkap. Sistem purusa adalah suatu sistem yang mendudukan status laki-laki sebagai status yang lebih utama dalam keluarga hindu. Ini dapat dipetik dalam Manawa Dharmasastra IX.137 "Putrena lokanjayati patrena anantamcnute, atha putrasya putrena bradhnasyapnoti wsitapam". yang artinya bahwa dengan memiliki keturnan laki-laki ia dapat menundukkan dunia, melalui cucu laki ia mencapai keabadian, tetapi melalui anak dari cucunya ia mencapai alam matahri. Selanjutnya MDS IX. 138 "Pumnamno narakadyas mattraya te pitaram sutah, tasmat putra iti proktah swayamewa swyambhuwa." Karena anak laki akan mengantar Pitara dari neraka yang disebut Put, karena itu ia disebut Putra dengan kelahirannya sendiri (Pudja dan Tjok Rasi Sudharta, 2002: 563-564). 
Penganut paham seperti di atas adalah sangat naïf, karena yang dimaksud dengan putra tidaklah hanya laki-laki melainkan seorang anak laki-laki ataupun perempuan. Disisi lain isi kitab Manawa Dharmasastra IX.133 menyebutkan bahwa anak laki-laki memiliki kedudukan yang sama dengan anak perempuan. " pautra dauhitrayorloka na wiceso'sti dharmatah, tayorhi mata pitarau sambhutau tasya dehitah" artinya: tidak ada perbedaan antara seorang anak laki dengan seorang anak perempuan yang diangkat statusnya karena semuanya disebut putra. Kewajibannya sama dengan masalah yang berhubungan dengan duaniawi ataupun dengan kewajiban suci, karena bagi ayah dan ibu mereka, keduanya dilahirkan dari badan orang yang sama (Pudja dan Tjokorda Rai Sudartha, 2002:562).

Paham tentang anak laki-laki yang hanya memiliki hak dan kewajiban di keluarganya, juga berimbas kepada beberapa daerah di Bali tidak diperkenannya adanya sistem perkawinan Nyentana/Nyeburin. Sistem perkawinan nyentana/nyeburin di Bali yaitu suatu sistem perkawinan, dimana dalam suatu keluarga bersepakat untuk mendudukan seorang anak perempuan diangkat statusnya menjadi anak berkedudukan purusa atau berkedudukan sebagai laki-laki, sehingga seorang laki-laki yang menikahinya berkududukan sebagai predana (perempuan) di rumah si wanita.

Sistem perkawinan nyeburin sudah biasa atau terkenal dianut oleh masyarakat Bali di Kabupaten Tabanan tidak terkecuali di Desa Mengesta. Tidak demikian halnya apabila dikaitkan dengan mendudukan seseorang sebagai pamangku, seorang laki-laki yang telah melakukan kawin nyeburin, dimungkinkan untuk dinobatkan sebagai pamangku utama, sedangkan istrinya tetap sebagai pendamping pamangku lanang. Sehingga si wanita tidak secara otomatis sebagai peganti pamangku yang menggantikan ayahnya walaupun dia sebagai pendamping suami bersama-sama dinobatkan dengan upacara pawintenan dan selanjutnya disebut dengan pamangku istri.

Berdasarkan asumsi pendekatan fungsional struktural, bahwa sistem ka-purusan di atas melihat struktur dan sistem pengangkatan pamangku sebagai bagian sistem sosial keagamaan masyarakat di Desa Mengesta. Struktur yang dimaksudkan adalah bagaimana anak laki-laki yang berstatus purusa dalam hubungan kekeluargaan ditetapkan sebagai pamangku, yang berakibat terhadap hak dan wewenang pamangku dalam menjalankan kewajibannya. Sesuai dengan asumsi kedua teori fungsional struktural, bahwa perubahan status dari masyarakat biasa menjadi pamangku dalam menjalankan kewajibannya memiliki sifat timbal balik, bahwa seseorang yang telah diberikan status baru tentunya juga diberikan imbalan dan wewenang, sehingga tidak adanya bias atau penyimpangan dari status dan kedudukannya.

Berdasarkan asumsi-asumsi di atas, masih menimbulkan suatu pertanyaan terhadap mereka yang melakukan perkawinan nyeburin yang telah ditetapkan sebagai pamangku utama dalam suatu pura, apabila si laki-laki nantinya meninggalkan rumah si wanita (bercerai), bagaimanakah kedudukan si laki-laki sebagai pamangku, apakah kedudukannya dianulir begitusaja yang disebut kapatita?. Menurut I Wayan Mertana diangkat sebagai pamangku yang dalam perkawinannya berstatus pradana, bahwa apabila terjadi perceraian dengan istrinya yang berstatus purusa, maka seorang laki-laki yang berstatus pradana di rumah si wanita, kedudukannya sebagai pamangku otomatis gugur dan status kepamangkuannya dikembalikan kepada pengemong pura, serta dia melakukan upacara mapamit (mohon diri) sebagai pemangku di pura yang diemongnya (wawancara, 2 april 2019). Demikian juga peristiwa penobatan pamangku di Desa Adat Belulang yang terjadi pada tanggal 28 Maret 2021, yang diangkat sebagai pamangku dalam perkawinannya berstatus pradana dalam system perkawinan nyeburin (Lana, wawancara, 17 Maret 2021)

Demikian juga asumsi ketiga dalam menelaah sistem kapurusa bahwa bagaimanapun penyimpangan pemahaman tentang gender dalam penetapan pamangku tentunya penyimpangan itu dicarikan suatu solusi atau consensus sehingga keseimbangan dalam perbedaan-perbedaan yang ada dapat diminimalisasi. Pada kasus di atas solusi yang diterapkan adalah tetap berpegang kepada sistem ka-purusan agar tidak menimbulkan masalah. Hal ini 
dilakukan karena dalam hubungannya dengan perceraian, seseorang laki-laki (status pradana) telah ninggalin kedaton dan ninggalin sesana. Artinya seorang laki-laki itu telah meninggalkan rumah istrinya dan meninggalkan kewajibannya sebagai pamangku. Untuk itulah sesuai dengan hukum adat Bali khususnya yang berhubungan dengan kewajiban-kewajiban yang diembannya bagi mereka yang berstatus pradana di rumah wanita secara otomatis putus, kecuali dalam hubungan hukum waris terhadap waris hasil gono-gini dan jiwadana selama mereka melangsungkan perkawinan diberlakukan berbeda.

\section{b. Faktor Dominasi laki-laki dalam kapamangkuan}

Berdasar teori ketimpangan gender sebagai alat analisis ketidakadilan gender yaitu, walaupun ciri manusia secara individual berbeda, namun tak ada pola perbedaan alamiah secara signifikan mengenai perbedaan pamangku lanang dengan pamangku istri. Apabila dinyatakan adanya ketimpangan gender itu berarti secara situasional pamangku istri kurang kekuasaan ketimbang pamangku lanang untuk memenuhi kebutuhan mereka bersama dalam rangka pengaktualisasian diri, ini bisa disebabkan oleh dominasi laki-laki terhadap perempuan.

Di dalam kitab Manavadharmasastra I.32, disebutkan, bahwa manusia diciptakan oleh Tuhan dengan membagi diri-Nya menjadi sebagian laki-laki dan sebagian perempuan (ardhanariswari). Ia menciptakan dari wanita itu sebagai Viraj (Pudja dan Sudharta, 2002:36). Viraj adalah aspek sakti yang disebut juga prakerti atau pradhana yang digambarkan sebagai wanita atau perempuan. Tanpa sakti atau power maka tidak akan ada ciptaan di jagat raya ini. Seperti dikutip tentang gender dari perspektif Veda dan Susastra Hindu di atas, ditegaskan oleh Mahatma Gandhi (dalam Titib, 2008:7) : I make no distinction between man and women. Women shuold feel just as independent as men. Bravey is not man monopoly". Berdasarkan penjelasan tersebut, maka permasalahan gender adalah masalah pengembangan potensi pada diri manusia.

Pernyataan di atas sangatlah ideal terhadap kesetaraan gender, tetapi kenyataannya dengan ideologi patriarki sebagai pengkontruksian gender pada masyarakat Bali, maka pendominasian laki-laki atas perempuan sering diperkuat oleh praktik keagamaan dan adat. Di dalam praktik keagamaan, pada tataran empirisnya bahwa upakara-upakara yang dibuat sering menyimbolkan purusa (laki-laki) dan predana (perempuan) dalam posisi berlawanan. Posisi berlawanan ini telah dipraktikkan pada saat manusia lahir ke dunia ini. Seperti apabila yang lahir ke dunia ini anak laki-laki, maka ari-arinya ditanam di sebelah kanan pintu masuk, sebaliknya ari-ari bagi anak wanita di tanam di sebelah kiri pintu masuk. Padahal pada proses perawatan ari-ari sebelumnya, baik upakara dan aksaranya, nyama bajang dan lain sebagainya tidak ada perlakuan yang berbeda.

Ketimpangan gender dalam penggunaan upakara pada upacara meningkat Dewasa (menek Deha) bagi anak perempuan. Upacara ini lebih dititik beratkan kepada anak wanita. Pada saat ini pandangan akan bias gender telah muncul serta pelabelan kepada anak wanita sebagai kaum yang lemah, di samping itu wanita lebih banyak menanggung akibat pertimbangan-pertimbangan yang keliru terutama mengenai asmara. Perempuan juga dianggap sebagai barometer untuk mengukur tinggi rendahnya atau runtuh-tegaknya martabat suatu keluarga/moral alam manusia. Ini dapat dijumpai di dalam Bhagavadgita I.41 sebagai berikut : Adharmabhibhavat krishna, Pradushyanti kulastriyah, Strishu dustasu varshneya Jayate varnasamkarah; " Jika adharma meliputi suasana o Krisna, maka para wanita dari kaum keluarga itu moralnya menjadi jatuh, Dan bila para wanita moralnya jatuh o Krisna, maka terjadilah kekacauan alam manusia. (Putra, Mas.tt:45).

Berdasarkan penjelasan di atas, jelaslah wanita dianggap sebagai sumber dari segala sumber keruntuhan moral keluarga, apabila seorang wanita melanggar norma-norma keluarga. Timbul suatu pertanyaan, bagaimana apabila laki-laki melanggar norma keluarga, apakah tidak menyebabkan runtuhnya moral keluarga? Telah jelas bahwa laki-laki tidak terlibat dalam 
menjaga moral keluarga karena laki-laki dianggap dapat mengatasi segala kekacauan dan memiliki kekuasaan untuk pembenaran atas tindakannya dari kaum perempuan.

Praktik dominasi dan hegomoni laki-laki atas wanita di Bali tidak hanya berdasarkan interpretasi agama melainkan juga melalui praktik-praktik struktur sosial, budaya, ekonomi, geografis, politik, pendidikan dan lain sebagainya yang mendudukan laki-laki sebagai insan kelas atas dan wanita sebagai insan atas kodratnya pada kelas bawah. Pada struktur sosial, dominasi laki-laki jelas terlihat pada sistem kepemimpinan, sistem politik, sistem pendidikan. Pada sistem kepemimpinan tradisional terlihat adanya dominasi laki-laki sebagai seorang pemimpin di desa adat. Realitasnya di desa adat bahwa wanita hanya sebagai pelengkap atau pendamping dalam keanggotaan masyarakat adat. Sehubungan dengan alam demokrasi, politik semakin terbuka, dalam menentukan pilihan calon pemimpin di desa adat wanita hanya dipakai meraup suara kemenangan sebagai asas demokrasi dalam dalih keterbukaan dan persamaan hak. Wanita tidak diperhitungkan untuk memimpin dan dapat dipilih dalam kepengurusan desa adat. Alasannya sangat lumbrah, karena wanita kurang kuat, belum paham tentang agama, hukum adat, tidak mempunyai kharisma dalam memimpin.

Dominasi seperti di atas, berimbas pula pada sistem kapamangkuan di Desa Mengesta. Pamangku lanang masih mendominasi pamangku istri. Dominasi ini terjadi pada saat seorang pemangku menyelesaikan upacara agama. Masyarakat penyelenggara upacara agama hanya memberikan satu undangan (pengoleman) kepada pamangku lanang, padahal pamangku istri ikut mendampingi pamangku lanang. Demikian sebaliknya pada saat upacara selesai, pamangku lanang dan pamangku istri hanya memperoleh satu (1) tehenan, bisa dalam bentuk daksina sebagai imbalan telah menyelesaikan proses upacara.

Ideologi yang melandasi pendominasian dan penghegomonian pamangku lanang atas pamangku istri diinternalisasikan ketimpangan pendidikan kapamangkuan lewat masyarakat adat, hanya pamangku lanang berhak menggunakan atribut kapamangkuan seperti penggunaan genta, mantra, nyupat, masupati upakara dan untuk menyelesaikan upacara agama. Hal ini dimaksudkan agar tetap terjaganya eksistensi masyarakat. Karena itu, memposisikan pamangku istri di bawah subordinasi pamangku lanang yang dipraktikan di desa Mengesta, ada korelasinya dengan peran masyarakat adat. Penobatan pamangku dilakukan atas azas garis keturunan laki-laki. Pembiasaan peran gender seperti ini menurut Fakih, bahwa mereka menerima peran gender tersebut sebagai suatu kodrat dan takdir yang harus diterima oleh kaum wanita (Fakih, 1996; Formm,2000 dalam Atmaja, 2004:64).

Penerimaan peran gender secara kodrati oleh wanita dapat pula dilihat pada awig-awig atau aturan-aturan desa adat Wongaya Betan Sargah I palet 4, paos 9, karena pada awig-awig ini tidak secara terang menyebutkan atau mengakui adanya pamangku istri.

1) Ring desa/banjar adat kawentenang Pamangku, Srati lan Sutri.

2) Pamangku, Srati, lan Sutri inucap keadegang melarapan antuk: (a)Ngelingin saking katurunan;(b) Kapilih saking Krama Desa/Banjar; (c) Saking Nyanjan.

3) Prabean upakaran ngawentenang (Adiksa Widhi) marep ring Pamangku penyade, Srati lan Sutri desa/banjar kemedalin antuk krama desa/banjar manut perarem.

4) Prabean upakaraning pitra yadnyane marep ring pamangku panyade Srati lan Sutri inucap ring ajeng ring sedane kapungkur sejawaning kamedalin antuk kulawarganya taler wenten kamedalin saking desa/banjar manut pareram.

5) Pamangku kengin kasanggra oleh panyade, manut kabuatan.

Terjemahan

1) Di desa/banjar adat diangkat pamangku, srati (tukang banten) dan Sutri

2) Pamangku, Srati, dan Sutri tersebut diangkat berdasarkan : (a) Berdasarkan keturunan; (b) Dipilih oleh warga masyarakat; (c) Berdasarkan upacara Nyanjan.

3) Biaya upacara mengangkat pamangku, Srati dan Sutri desa/banjar dibiayai berdasarkan urunan warga desa berdasarkan hasil keputusan rapat. 
4) Biaya upacara Pitra yajna (kematiannya) kepada pamangku, Srati dan Sutri yang dinobatkan seperti di atas, pada saat meninggalnya selain di biayai oleh keluarganya juga dibiyai oleh krama Desa berdasarkan hasil keputusan rapat.

5) Pamangku dibenarkan diganti oleh wakilnya berdasarkan keperluan.

Berdasarkan paparemnya, tidak ada menyebutkan biaya dan hak yang diterima oleh pamangku istri karena di sana hanya disebutkan secara umum. Menurut I Made Sudira, masyarakat desa adat sering melupakan terhadap kewajibannya untuk memberikan patus berupa imbalan kepada pamangku istri saat meninggalnya (Wawancara, 16 April 2019). Ini menandakan bahwa pamangku istri belum diperhatikan dalam hal hak dan wewenangnya dalam bidang keagamaan. Berkenaan dengan budaya nerimo sesuai kodratnya, maka pamangku istri hanya bertindak sebagai pendamping, pada peristiwa pamangku lanang telah meninggal, pamangku istri tidak diberdayakan oleh masyarakat, justru masyarakat segera mencari peganti pamangku.

\section{c. Faktor Pendidikan}

Pendidikan dinyatakan sebagai agen perubahan (agent of change) memegang peran penting untuk memberikan kontribusi pemahaman peran gender dalam masyarakat Bali. Pendidikan sebagai salah satu unit perubahan sosial dalam bidang spiritual keagamaan menempatkan laki-laki dan perempuan pada posisi sederajat dalam hubungan kepada yang dipuja yaitu Tuhan. Untuk itu dimungkinkannya transformasi pengetahuan perempuan atas dominasi laki-laki dalam bidang keagamaan dapat berada pada posisi sama, karena Veda sangat mengajarkan egalitarianisme, bahwa manusia sama dihadapan Tuhan.

Pada budaya lokal Bali banyak nilai-nilai pendidikan untuk menjadikan anak wanita Bali sebagai tulang punggung penerus pendidikan keluarga, karena pendidikan anak-anak pertama dan yang paling utama didapatkan dari keluarganya terutama dari seorang ibu. Nilainilai pendidikan seorang anak diharapkan menjadi "anak luh luih" atau anak wanita yang santun dan berguna di masyarakat, bukan "anak luh luu" atau anak wanita sebagai sampah masyarakat.

Pendidikan kepada anak wanita di Bali pada zaman dahulu lebih banyak pada pendidikan keterampilan (psikomotorik) yang mendukung pekerjaan domestik bagi seorang ibu. Hal ini maksudnya agar seorang anak wanita setelah menikah tidak merasa canggung, dan siap untuk membantu pekerjaan rumah tangganya, seperti mencuci, memasak, membuat upakara, serta pekerjaan domestik lainnya. Untuk itu, pendidikan formal untuk menuntut ilmu pengetahuan di sekolah sering diabaikan, karena menganggap wanita tidak perlu bersekolah, yang nantinya hanya sebagai ibu rumah tangga. Seiring dengan perkembangan ilmu pengetahuan dan teraksesnya pendidikan sampai ke pedesaan, bahwa pada tahun 1970 sampai tahun 1980 diadakan program Pemberantasan Buta Huruf (PBH), yang sasarannya kepada ibuibu yang tidak pernah mengenyam pendidikan formal. Perubahan pandangan kaum ibu-ibu mengenai pentingnya pendidikan dan ilmu pengetahuan sedikit-demi sedikit mulai berubah. Pendidikan anak wanita mendapat perhatian dari para orang tuanya untuk dapat mengejar ketertinggalan pendidikan dari kaum laki-laki.

Suborniasi atau penomerduaan pendidikan wanita pada jaman itu masih menjadi suatu budaya, tidak ketinggalan pada tataran pendidikan agama, walaupun institusi lembaga keagamaan dan institusi lembaga pendidikan agama telah ada, tetapi secara empiris masih menomorduakan peran kaum wanita sebagai pemimpin upacara. Perempuan di jaman sekarang inipun masih menjadi objek bukan subjek. Marak terjadinya eksploitasi dan pembelengguan hak-hak perempuan hampir di seluruh masyarakat dunia. Perempuan semata-mata dijadikan objek dan jargon profesi. Jumlah perempuan yang secara kuantitas sama dengan laki-laki, namun secara kualitas peran publik didominasi oleh laki-laki. Kebijakan yang syarat dengan kekuasaan, hampir tidak tersentuh oleh kebanyakan kaum perempuan. Bahkan, dalam acara ritual keagamaan banyak sekali gerakan yang menggugat peran laki-laki mengatur dan 
mengebiri kaum perempuan (Naqiyah, 2005:111). Hal ini juga tampak pada teks-teks Dharmasastra seperti dalam Manu (5.145) diyatakan bahwa perempuan dinytakan tidak perlu menjalani upacara korban, melakukan penyembahan ataupun berpuasa. Wanita mendapatkan posisinya paling tinggi di surga dengan setia melayani suaminya.

Praktek Suborniasi ditemukan, bahwa anak perempuan setelah mereka menginjak dewasa sudah tidak mendapat perhatian oleh orang tuanya untuk mendapatkan layanan ritual khususnya upacara otonan pada hari kelahirannya. Anak wanita dianggap setelah menikah akan hidup di keluarga suaminya, sedangkan anak laki-laki sampai lanjut usia masih mendapatkan upacara otonannya. Demikian pula pada pendidikan kapamangkuan masih mengutamakan kepada pamangku lanang (laki-laki) sebagai pemimpin upacara, mengucapkan mantra dan menggunakan genta/bajra. Pamangku istri lebih banyak dididik pada pekerjaan dan penguasaan dibidang sarana upacara, karena masih menganggap bahwa pekerjaan pamangku istri sebagai pedamping pamangku lanang. Budaya masyarakat Bali dalam kapamangkuan menempatkan kaum perempuan pada subordinat, dengan membatasi ruang gerak perempuan dalam bidang kapamangkuan.

Penomorduaan perempuan dalam pendidikan kapamangkuan sampai dewasa ini menimbulkan kesenjangan, antara pamangku lanang dan pamangku istri. Sehingga masalah akan timbul apabila pamangku lanang terlebih dahulu meninggal, maka kewajiban sebagai pamangku seharus dilanjutkan oleh istrinya. Tetapi dengan keterbatasan pendidikan dan jarangnya tampil sebagai publik figur seorang pamangku, maka pamangku istri merasa tidak siap untuk memimpin sebuah upacara, sehingga masyarakat menyiapkan pamangku panyade atau pengganti terhadap pamangku istri, karena sudah dianggap tidak cakap dalam melayani umatnya. Padahal pawintenan kapamangkuannya sama dengan pamangku lanang.

\section{d. Faktor Pelabelan}

Teori pelabelan mensyaratkan sebuah rekonseptualisasi atas keseluruhan bidang kajian penyimpangan. Alih-alih mengansumsikan definisi penyimpangan seperti apa adanya dan berusaha menerangkan pelaku penyimpang, pendekatan ini lebih direkomendasikan untuk melihat penyimpangan sebagai problematika subyektif, relatif, dan berubah (Kuper,2000:537). Teori ini dapat dipakai untuk mengkaji terhadap pembentukan stereotipe wanita, karena wanita telah dianggap dalam kelahirannya sebagai suatu penyimpangan sehingga dilabelkan manusia kelas bawah (under class) sedangkan laki-laki berstatus (upper class). Wanita juga dianggap mengalami stigmata, mendapat sebutan atau label under class, mudah emosional, label ibu rumah tangga, genit, sehingga pelabelan ini banyak merugikan perempuan. Pelabelan negative kepada perempuan Bali, dapat mempersulit untuk mengembangkan potensi dirinya, berkreativitas, serta sulit untuk keluar dari pencitraan negatif sebagai wanita. Sehubungan dengan kapamangkuan, maka pelabelan terhadap pamangku lanang dan pamangku istri, memilki makna denotatif, yakni pamangku lanang adalah orang yang lebih berpendidikan, lebih senior dalam segala hal, tetapi juga bermakna konotatif, yakni pamangku lanang lebih berhak menjalankan kewajiban kapamangkuanya atas keturunan purusa, dan dapat melindungi pamangku istri dalam menjalankan kewajibannya.

Ideologi gender menekankan pada peran gender, yakni peran pamangku istri sebagai pengelola dan pelaksana utama pada sektor domestik kapamangkuan dengan dalih seorang wanita lebih memiliki emosional lemah lembut, memiliki kesabaran tinggi, memiliki ketrampilan seni dari laki-laki, maka itu tugas domestik seperti mejejahitan, membuat jajan upakara, menarikan tarian sakral, bernyanyi (mekidung) sebagian besar dilakukan oleh pamangku istri. Sedangkan ideologi patriarki tidak saja menentukan posisi pamangku istri sebagai kelas bawah pada struktur sosial kapamangkuan, tetapi juga pada pendistribusian kekuasaannya. Pamangku lanang memiliki kekuasaan dan wewenang sebagai pemimpin upacara, melantunkan mantra, menggunakan gentalbajra, memercikan tirtha, membuat sarana upacara khususnya yang berhubungan dengan membunuh binatang upacara, ngebat (mengolah 
sarana daging upacara), membuat penjor, membuat kelatkat, dan lain sebagainya, karena pamangku lanang dianggap lebih rasional, aktif dan kreatif dan makhluk budaya. Sedangkan pamangku luh adalah makhluk emosional, pasif, dan makhluk alamiah.

Gagasan tentang, pelabelan laki-laki dan perempuan, purusa dan pradana yang di Bali disebut Purus dan Bagha, telah ada sejak perdebatan-perdebatan para sarjana filsafat Hindu tentang proses penciptaan utamanya filosof Samkhya. Filsafat samkhya disebut dualistic karena mengukuhkan ada dua realitas yang paling mendasar serta berdiri sendiri, saling bertentangan, tidak ada perpaduan antara satu dengan yang lainnya, yaitu purusa dengan prakerti atau rokh dengan benda. Gagasan ini diaplikasikan dalam falsafah hidup masyarakat Bali untuk membedakan dua sisi yang saling bertentangan seperti kaja (utama) - kelod (nista), gunung (suci) dan lautan (profan), laki - perempuan (purusa-pradana), hulu (utama) - teben (nista). Demikianlah selanjutnya, bahwa pelabelan laki-laki sebagai manusia utama dan wanita berstatus lebih rendah pada kelas bawah, ini berakibat pada penentuan bidang pekerjaan, tanggung jawab, hak dan kewajiban.

\section{e. Faktor Mitos Menstruasi}

Aturan-aturan bagi siapa bisa menjadi pamangku tidak ada secara tegas diuraikan dari beberapa susastra Hindu maupun aturan-aturan adat yang berlaku. Selama ini aturan-aturan itu hanya menyangkut etika, moral, dan siapa yang terpilih sesuai dengan tata cara pemilihannya. Sedangkan berdasarkan umur, itu tidak pernah ditetapkan karena selama ini pamangku bisa dinobatkan atau diwinten secara pilihan, keturunan dan nyanjan, sehingga kemungkinan besar kedewasaan secara biologis dan umur belum tentu terpenuhi demikian juga kedewasaan jiwanya karena dimungkinkan mereka menjadi pamangku masih remaja yang terpilih dengan upacara nyanjan. Menurut Lupton (dalam Abdullah, 2006:213-214) menstruasi sebagai proses biologis yang normal bagi setiap wanita. Pada periode menstruasi dinyatakan sangat merugikan bagi kaum perempuan, karena masa menstruasi ditabukan untuk melakukan hubungan seks dan melaksanakan peribadatan. Sehubungan dengan peran pamangku, maka pamangku istri yang masih dalam masa kesuburan sedang menstruasi sangat pantang untuk melaksanakan kegiatan upacara-upacara keagamaan. Menurut Freud mentruasi dianggap tabu, kotor, terkena kekuatan jahat, sebagai isu yang dapat dimanfaatkan untuk kepentingan politik. Hal ini merupakan cerminan dari sikap masyarakat yang ambivalen terhadap perempuan. Hal ini sering dipelihara secara magis dalam suatu masyarakat sehingga menjadi suatu common sence dan realitas yang baku. (Delaney, dalam Irwan Abdullah, 2006:215).

Pada kehidupan sosial masyarakat Hindu di Bali juga mempraktekkan mitos-mitos menstruasi terhadap wanita, sehingga wanita kurang mendapatkan kesempatan yang sama dengan kaum laki-laki. Dapat diperhatikan pada aturan-aturan masuk pura di Bali, bahwa tidak diperkenankannya bagi wanita yang sedang menstruasi untuk masuk ke dalam Pura karena di anggap mengotori tempat suci, dan para Dewapun menjauhinya. Secara normal wanita yang sedang mentruasi memang sangat terganggu dalam berbagai aktivitas keagamaan, akan tetapi secara etika sosial perempuan memiki kesempatan yang sama untuk menjalankan aktivitas ritual dan spiritualnya, tidaklah benar menstruasi sebagai alasan menempatkan wanita nomor dua dalam kegiatan ritual keagamaan. Khususnya, dalam aktivitas wanita sebagai seorang pamangku, dimana pamangku istri tidak diberikan porsi yang sama dalam mengantarkan suatu upacara agama.

Ketimpangan gender dalam hubungannya dengan mitos menstruasi jelas terlihat adanya rasa takut dari masyarakat desa Mengesta, apabila seorang pamangku istri seketika datang bulan (mestruasi) pada saat melaksanakan aktivitas kapamangkuannya, sehingga meganggu tatanan sosial. Di samping mengganggu tatanan sosial juga dianggap mengganggu kesucian pura (tempat suci), maka keheningan masyarakatpun terganggu. Oleh karena demikian, maka pamangku istri diberikan tugas yang sifatnya membantu pamangku lanang. 


\section{Pengenderan atas Kapamangkuan di Desa Mengesta a. Pelabelan Pamangku Lanang dan Pamangku Istri}

Label adalah suatu citra yang menunjukkan suatu produk tertentu. Seorang wanita yang dilabeli dengan kata istri, stri menandakan seorang wanita yang telah bersuami. Pada praktek kapamangkuan, bahwa sebutan pamangku istri menunjuk kepada seorang wanita yang telah menjadi pamangku. Tetapi kata istri juga menjadi bias atau menyimpang dari arti yang ditempelkan pada wanita yang telah bersuami pada praktek kapamangkuan, khususnya kepada pamangku wanita yang belum bersuami juga disebut dengan nama pamangku istri. Istri, dalam hal ini memberikan kata istri sebagai cara memperhalus terhadap status seseorang yang dihormati sebagai pamangku.

Untuk menyandang kata istri di belakang kata pamangku dibenarkan sebagai suatu penghormatan menurut Veda Semerti yaitu Manawa Dharmasastra II.128 sebagai berikut : "Awacyo diksito namna, Yawiyanapi yo bhawet, Bhobhawat purwakam, Twenamabhibhaseta dharmawit" : Ia yang sudah diwinten untuk melakukan Srauta, hendaknya tidak boleh dipanggil dengan menyebut namanya, walaupun ia masih muda; ia yang tahu peraturan suci seharusnya mempergunakan kata "bhoh" dan memakai panggilan "Bhawati" (yang terhormat) kepada orang yang demikian dalam berbicara (Pudja \& Tjok Rai Sudharta, 1995:98).

Pemanggilan nama pamangku lanang dan pamangku istri ini telah dibiasakan oleh masyarakat di desa Mengesta sebagai suatu penghormatan atas tugas yang berbeda dengan masyarakat kebanyakan. Kata istri berasal dari bahasa Sansekerta, yakni stri. Kata stri terdiri dari tiga suku kata, sa, ta dan $\mathrm{ra}$. Sa adalah swabhimaanam yang berarti harga diri. Ta adalah thyagan yang berarti berkorban. $R a$ adalah rasa yang terkait dengan rasa manis (Fracassi dan Urbani, dalam Bawa Atmaja, 2004:71). Apabila dilihat dari definisi istri, maka dapat didekontruksi bahwa kata istri dalam label pamangku istri menunjukkan sosialisasi wanita ke dalam polaritas gender. Hal ini diperkuat dengan pemakaian kata istri di belakang kata pamangku sebagai label mempunyai kewajiban berbeda dengan kewajiban orang kebanyakan serta mengacu kepada realitas maupun harapan bahwa pamangku istri mempunyai posisi yang lebih terhormat dari pada masyarakat kebanyakan lainnya. Pemangku istri menunjuk pada suatu ikatan antara pamangku lanang yang memiliki kewajiban untuk mengemban umat hindu secara bersama-sama di dalam suatu komunitas desa adat atau lingkungan pura yang di emponnya, di mana mereka bertugas sebagai pamangku.

Makna yang terkandung pada label istri/stri pada pamangku istri memberikan peluang bagi pamangku lanang untuk menuntut pamangku istri agar menjalankan kewajibannya sebagai istri pendamping suami dalam menjalankan kapamangkuannya guna melaksanakan tugas-tugas domestiknya membuat banten (sarana upacara), dan menyediakan pelayanan dalam pelaksanaan tugas. Ini sejalan dengan penggenderan aktivitas pamangku istri yang tidak mempunyai kemandirian dalam beraktivitas, karena aktivitasnya mesti di bawah pengawasan laki-laki. Kitab Manawadharmasastra Buku IX sloka 11 disebutkan bahwa wanita "Arthasya samgraha cainam, Wyaye caiwa niyojayet, Cause dharme'nnapaktyam, Ca parinahyasya ceksane": Hendaknya suami mengerjakan istrinya didalam pengumpulan dan pemakaian harta suaminya dalam hal memelihara segala sesuatu tetap bersih, dalam hal melakukan kewajibankewajiban keagamaan di dalam hal penyediaan santapan suaminya dan menjaga alat peralatan rumah tangga (Pudja \& Tjok Rai Sudartha, 1995: 528).

Berdasarkan sloka di atas apabila dihubungkan dalam konteks kapamangkuan sangat jelas menekankan pada penyediaan dan pelayaanan pada suami dalam kewajiban-kewajiban keagamaan bagi suaminya. Ini menunjukan pada egosentris pemangku lanang sebagai laki-laki simbol kekuasaan dan menjaga kehormatan kelaki-lakiannya bahwa dia yang mampu untuk melaksanakan kewajiban keagamaan. Sehingga pamangku istri tidak memiliki kesempatan untuk meningkatkan dirinya dalam mempelajari Veda (mantra), karena telah diberikan tugas sebagai pelayan pamangku lanang. 
Jadi, tidak ada kebebasan bagi wanita baik yang bersifat individu maupun yang bersifat umum. Robert C. Zaehner (dalam Arniati, 2004:49) dinyatakan, bahwa seorang wanita, menurut ajaran agama Hindu, tidak pernah svatantra, dia tidak pernah "mempunyai suatu pertalian dari dirinya sendiri"; dia bukanlah nyonya untuk dirinya sendiri. Namun, komentar itu menjadi keliru, manakala merujuk pada Yajurveda XIV.21 menyebutkan "wahai wanita engkau adalah perintis, cemerlang, mantap, pendukung, yang memberi makan dan menjalankan aturan-aturan seperti bumi. Kami memiliki engkau dalam keluarga untuk usia panjang, kecemerlangan, kemakmuran atau kesuburan pertanian dan kesejahteraan (Titib,1996:416).

Uraian tentang svatantra dalam menjalankan kewajiban keagamaan disebutkan dalam Manawadharmasastra IX.96 sebagai berikut: untuk menjadi ibu wanita itu diciptakan, untuk menjadi ayah laki-laki itu diciptakan, untuk itu upacara keagamaan hendaknya dilakukan oleh suami dengan istrinya secara bersama-sama (Pudja \& Tjok Rai Sudharta, 1995:551). Sangat jelas, kewajiban keagamaan bagi seorang pamangku lanang dan pamangku istri hendaknya dilakukan secara bersama-sama ataupun apabila pamangku lanang berhalangan untuk melakukan kewajibannya, maka pamangku istri dapat mewakili pamangku lanang dalam melakukan tugasnya sebagai pamangku.

\section{b. Penggenderan Melalui Sistem Pendidikan Kapamangkuan}

Menurut Titib (2008:3) disebutkan menurut perspektif Veda dan Susastra Hindu telah tampak adanya kesetaraan gender, dan bahkan dalam aspek pendidikan anak perempuan mendapatkan tempat yang sangat mulia, karena perempuan akan menjadi ibu dan sekaligus guru yang pertama dan yang utama (nasti guru samo mata, tidak ada yang melebihi seorang ibu sebagai guru. Kitab suci Atharvaveda (XIV.2.20) dijelaskan melalui sebuah mantra yang dinyatakan bahwa seorang wanita hendaknya senantiasa memuja dewi Saraswati dan menghormati orang tua dan keluarga. Pemujaan kepada dewi Saraswati mengandung makna untuk mendalami ilmu pengetahuan dan menghormati orang tua dan keluarga, menanamkan budipekerti kepada dirinya sendiri dan keluarga atau anak-anak yang akan dilahirkan nanti.

Susastra Hindu dan Veda sangat ideal sebagai pegangan bagi masyarakat untuk memberikan kesempatan yang sama kepada wanita untuk belajar Veda. Tetapi berbeda halnya dengan di lapangan, bahwa banyak anak-anak wanita tidak mendapatkan pendidikan sepantasnya, karena pandangan masyarakat dan orang tua yang pendidikannya terbelakang mengatakan wanita nantinya hanya sebagai seorang istri penjaga rumah, istri pendamping suami, istri penjaga anak-anak dan orang tua, istri sebagai penyedia segala sesuatu berhubungan dengan keagamaan dan rumahtangga. Di satu sisi, orang tua sering menuntut anaknya untuk menjadi luh luih, yaitu wanita yang berguna bagi keluarga dan dapat mensejahterakan keluarga, bukan luh luu atau wanita seperti sampah tidak berguna bagi keluarganya. Akan Tetapi pendidikan bagi seorang wanita dinomorduakan, ini bermula pada pendidikan di keluarga, wanita hanya diberikan pendidikan domestik, sehingga wanita pada keluarga Hindu menjadi subornitas laki-laki.

Pada era global dan kemajuan pendidikan dewasa ini orang tua semakin terbuka memberikan anak wanitanya untuk mendapatkan pendidikan yang lebih tinggi, disamping pendidikan rumah tangga. Seorang ibu berkewajiban untuk mengemban peran gender pada anak wanitanya dengan cara menata teknologi permainannya. Jenis permainan yang sangat disukai oleh wanita pada umumnya yang terkait dengan gender, misalnya menirukan wanita yang berjualan (medagang-dagangan), memasak (mapaon-paonan, memasak-masakan), mengasuh anak lewat permainan boneka, dalam perspektif psikologis, wanita memiliki pengaruh sangat besar dalam konteks menjadikan makhluk feminim menjadi wanita atau istri.

Terkait dengan pendidikan agama sebagai penggenderan, maka permainan medagangdagangan atau memasak-masakan di atas dilanjutkan dengan mesaiban atau menghaturkan sesajen setelah memasak. Ini merupakan penginternalisasian peran gender dengan cara peniruan dari apa yang dilakukan oleh orang tua (ibunya) setiap hari sehingga menjadikan 
kebiasaan anak wanita untuk menghaturkan saiban sehabis memasak. Peniruan ini berlanjut tidak sebatas hasilnya saja melainkan juga dengan menghaturkannya dimana biasanya orang tua menghaturkan sesajen. Pada proses pendidikan ini anak wanita lebih banyak diberikan pelatihan yang terkait dengan peran keibuan, sebaliknya anak laki-laki lebih diutamakan pada pelatihan peran kebapakan. Peran keibuan mengacu kepada "fungsi wanita dalam kapasitasnya sebagai orang yang diminta, bukan yang meminta; orang dinikmati, bukan yang menikmati" (Ibrahim, 2002:54).

Berbicara mengenai pendidikan pamangku sudah tentu interpretasi ada pada pendidikan yang diberikan kepada pamangku lanang seperti adanya pendidikan pinandita yang diselenggarakan oleh lembaga-lembaga pendidikan keagamaan. Kuantitas peserta pendidikan pamangku lebih banyak diikuti oleh mereka yang berstatus pamangku lanang (laki-laki). Sedangkan pamangku istri diarahkan pada pendidikan kapamangkuan khususnya pada pendidikan tukang banten (membuat upakara), kecuali pada materi-materi umum seperti sasananing pamangku. Sedangkan untuk materi khsusus seperti pendidikan kapanditaan dalam hubungannya dengan penggunaan genta, mengucapkan mantra dan wewenang kapamangkuan lebih banyak diberikan kepada pamangku lanang.

Dominasi laki-laki dalam pendidikan kapamangkuan sangat jelas pada status purusa di lingkungan keluarga yang menganut sistem patriarkhi. Pendidikan untuk mengetahui sifat-sifat seorang pamangku, melatih keberanian, tanggap akan hubungan kepada yang supranatural (niskala) ditunjukkan oleh orang tua kepada anak laki-lakinya untuk mendalami dan mempraktekkan kepada hubungan niskala tersebut. Agar supaya si anak itu telah terlatih sejak kecil, sehingga nantinya tidak canggung pada saat menggantikan ayahnya menjadi pamangku. Realitas ketidakadilan yang disebabkan oleh bias gender tentang kapamangkuan ini disebabkan oleh pandangan tentang kemampuan pengembangan diri seorang perempuan. Seperti pendapat Mahatma Gandi yang dikutif Titib (2008:7) "I make no distinction between man and women. Women should feel just as independent as men. Bravery is not man monopoly”. Dikatakan berdasarkan penjelasan tersebut, maka permasalahan gender adalah masalah pengembangan potensi pada diri manusia. Adanya ketidaksetaraan gender seperti diungkapkan oleh Naurah Najwa Hairudin terletak pada kemampuan pengembangan potensi manusia, khususnya potensi kaum perempuan.

Terhadap pandangan tersebut peneliti memiliki sedikit pandangan yang berbeda, memang benar masalah gender adalah masalah pengembangan potensi diri, tetapi banyak kesempatan yang tertutup bagi kaum perempuan untuk pengembangan potensinya guna berjuang setara dengan laki-laki, seperti kesempatan pendidikan pamangku istri untuk mempergunakan Bajra (genta) serta Mantra. Pendidikan yang diberikan lebih banyak pada pembuatan sarana upacara (mejajahitan).

\section{c. Sistem Perkawinan kedua sebagai penggederan kapamangkuan}

Penggenderan atas wanita dalam menjaga kesucian perkawinan. sehubungan dengan kapangkuan, bahwa seorang wanita juga mendapatkan tekanan dalam menentukan calon suami yang berstatus pamangku. Pamangku lanang diperkenankan untuk melakukan pernikahan lagi dengan seorang wanita apabila istri pertamanya telah meninggal atau melakukan perceraian karena istrinya melakukan perbuatan yang tidak baik.

Dalam lontar Tattwa Siwa Purana diuraikan sebagai berikut:

......yan sampun madeg Pamangku, tan kawenang cemer; yan wenten Pamangku malih mengambil rabi, ri wusnia mapawarangan, wenang sira mangku manyepuh pawintenan nguni. Mwah ngaturang pasapuh ring pura, mwah wadone punika wenang nyepuh. Apang tan kari kareketan letuh, yan tan nawur penyapuh, tan kawenang ka pura. Yan marabi saking paiccan nabe, mwang guru wisesa, kalih saking pakramane ngaturin marabi, punika dados ngaturang pangrebu alit, ring pura pura nenten ja masapuh. 
Terjemahan:

... kalau sudah menjadi Pamangku, tidak boleh cemer; kalau ada Pamangku beristri baru, setelah selesai upacara perkawinannya patut Pamangku itu melaksanakan upacara nyepuh pawintenannya yang lalu dan lagi menghaturkan upacara pasasapuh di pura, dan istrinya itu patut melaksanakan upacara nyepuh. Supaya tidak terkena letuh (cemar), kalau tidak melaksanakan upacara penyapuh tidak diperkenankan ke pura. Kalau mengambil istri karena pemberian guru atau pemerintah maupun dari warga masyarakat yang memberikan atau menyuruh beristri, diperkenankan hanya menghaturkan upacara pangrebu yang sederhana di pura, tidaklah dengan upacara penyapuh.

Ketentuan dalam teks lontar di atas mengatur tentang kewajiban pamangku apabila melakukan perkawinan kedua setelah istrinya meninggal atau bercerai, ataupun apabila seorang pamangku yang dinobatkan sebagai pamangku sebelum mempunyai istri. Apabila ia melakukan perkawinan kedua disebut cuntaka (tidak suci), maka wajib melakukan upacara penobatan (pawintenan) seperti upacara pawintenan yang pertama.

Perlakukan ketidakadilan gender dalam kapamangkuan dalam hubungan perkawinan ini terjadi di desa Mengesta desa Pakraman Wongaya Betan. Menurut I Nengah Weda bahwa dia sebagai seorang Pamangku melakukan perkawinan kedua dengan seorang wanita yang berstatus janda. Perkawinan ini menjadi kontroversial karena masyarakat desa adat mempunyai perbedaan pendapat. Di satu sisi membolehkan perkawinan pamangku itu dengan seorang janda dengan syarat seperti isi lontar di atas yaitu dilakukan upacara pawintenan kembali. sebaliknya, ada masyarakat tidak memperkenankan perkawinannya dengan janda dianggap leteh (tidak suci) atau tidak benar. Keputusan paruman krama desa adat, secara mufakat untuk memberhentikannya dan mrncari pengganti sesuai tatacara pemilihan pemangku dengan upacara Nyanjan. (Wawancara, 15 April 2019).

Apabila disimak hasil wawancara tersebut, terlihat adanya merendahkan kedudukan seorang wanita yang memiliki naluri kebutuhan jasmani dalam menentukan pilihan hidupnya mendapatkan perlakukan nomor dua atas laki-laki. Janda masih dianggap hina, tidak suci, padahal seorang wanita tidak menginginkan untuk berstatus janda, wanita selalu menginginkan perkawinan yang langgeng dengan suaminya, tetapi nasib perjalanan hidupnya memberi arah yang lain. Sebagai suatu pertanyaan, apakah wanita yang belum pernah bersuami sudah pasti ia suci, padahal dalam perjalanan hidupnya tidak diketahui oleh orang lain, apakah dia hidup dengan moral yang baik atau sebaliknya. Apabila ia sebelum memiliki suami melakukan perbuatan amoral yang tidak diketahui oleh masyarakat umum, apakah layak ia disebut masih suci. Ini sangat sulit dan menjadi dilema bagi mereka yang mengambil keputusan atas kesucian seseorang yang boleh dijadikan istri.

Di dalam Manawadahramasastra IX. 23-24 telah jelas disebutkan : "Aksamala wasisthena samyukta dhamayonija, Caranggi ,andapalena, jagamabhyarhaniyatam" : Aksamala, adalah wanita dari kelahiran hina, karena kawin dengan bhagawan wasistha, demikian pula Seranggi yang kawin dengan Mandapala, (mereka) menjadi layak mendapat kehormatan. Etaccanyacca loke"smin, Na pakrista prasutayah,Utkarsam yositah praptah, Swaih swair bhartrigunaih cubhaih.:Mereka ini dan lain-lain wanita keturunan hina telah mencapai kemasyurannya di dunia hanya karena sifat-sifat yang mulia dari pada suami mereka (Pudja \& Tjok Rai Sudharta, 1995:531-532)

Penjelsan sloka di atas, bahwa Aksamala atau Arundhati adalah nama wanita tergolong rendah (candala atau sahaya) tetapi ia menjadi wanita yang terhormat karena menikah dengan Bhagawan Wasistha, salah satu maha Rsi dan kedudukannya diakui sederajat oleh kitab Cruti Weda (Cruti atau wahyu). Kebiasaan (lokayatra) yaitu tingkah laku yang umum dianut oleh setiap orang di dunia dan akan selalu demikian (nityam = selalu demikian), merupakan suatu hukum kebiasaan yang berlaku umum yang mengatur perihal hubungan tentang orang bersuami istri. 
Arah pemikiran sloka di atas dapat dianalisa sebagai suatu pedoman bagi setiap masyarakat agar tidak merendahkan wanita karena berlaku umum laki-laki dan wanita untuk melakukan hubungan sebagai suami istri, yang terpenting bagaimana perkawinan atau hubungan itu dilakukan berdasarkan norma hukum dan norma agama. Apabila dilihat dari pemaparan wawancara di atas, walaupun seorang laki-laki hanya berstatus pamangku bukan seorang maha Rsi tetapi berstatus disucikan oleh masyarakat dengan nalurinya dia harus memiliki pendamping seorang istri untuk melakukan kewajibannya, maka ia layak untuk melakukan perkawinan lagi walaupun calon istrinya adalah seorang janda.

Sangat ironis lagi, apabila seorang pamangku selalu menduda yang tidak bisa menahan naluri kelaki-lakiannya bisa terjadi dia melakukan hubungan layaknya suami istri di luar tnorma hokum dan norma agama. Di satu sisi bisa menyebabkan ketidak sucian individu pemangku dan keluarganya, di sisi lain menyebabkan ketidak sucian lingkungan masyarakat maupun tempat suci atau pura dimana ia melakukan kewajiban. Maka lebih terhormat pihak pamangku lanang memperoleh seorang istri, demikian pula sang istri sangat terhormat memperoleh calon suami seorang pamangku apalagi dirinya dapat melaksanakan kewajibannya dengan baik, serta tetap melakukan upacara penobatannya kembali.

Ketidakadilan ini tampak pada faktor penyebab interpretasi yang salah atau bias terhadap suatu ajaran agama. Hal ini menunjuk pada kekuasaan seorang laki-laki yang selalu dianggap berada pada perilaku yang suci padahal bisa sebaliknya seorang laki-laki bisa melakukan perbuatan yang amoral. Falsafah "wanita ternoda dunia menangis, pria berdosa dunia tertawa" yang maksudnya bahwa keluarga akan dihormati tergantung dari moral seorang wanita, dalam artian norma-norma keluarga diikuti dan dihormati apabila wanita-wanita dalam keluarga itu berkelakukan baik dan suci. Sedangkan seorang laki-laki melakukan perbuatan yang tidak baik, dikatakan dunia ini tertawa atau dunia ini tidak pernah memberikan penilaian buruk kepadanya. Pada gambaran seperti ini terlihat terpengaruh struktur sosial yang patriarki, yang memposisikan wanita subordinat dalam relasi pria dan wanita.

\section{d. Penggenderan Melalui Pakaian Pamangku}

Identitas seorang pamangku dapat diidentifikasi melalui pakaian yang dipergunakan dalam melaksanakan kewajibannya sebagai pamangku, yang dapat membedakan dengan masyarakat biasa dan masyarakat yang menekuni profesi lainnya dalam hubungan keagamaan. Pamangku kahyangan atau Pura sesuai dengan ketetapan Sabha Parisada Hindu Dharma Ke II No. V/Kep./PHDP/68 tentang Tata Keagamaan (Kesulinggihan, Upacara dan Tempat Suci) menentukan pakaian Pinandita (PHDP, Dana Ed. 2005:47-48).

Pakaian pamangku dalam melaksanakan tugas kapamangkuannya terdiri dari a. destar (udeng) berwarna putih; Kwaca (baju) berwarna putih; Kampuh (saput) berwarna putih atau kuning; Wastra (kain) berwarna putih; memakai dandanan rambut yang ditutup destar berbentuk bongkos nangka (seperti membungkus buah nangka) yang disebut dengan magelung anyondong, Suhardama (2006:24-25).

Demikian pula diuraikan pakaian pamangku dengan gelar Jero Gede, akan tetapi tidak sedikitpun membahas mengenai pakaian pamangku istri, hal ini menunjukkan adanya penggenderan atas pakaian pamangku. Ataupun dalam hal mengolah pakaian pamangku istri sebagai simbol sosial maupun simbol keagamaan tidak pernah diperhatikan, karena pengambil kebijakan maupun masyarakat sama memandang bahwa pamangku istri adalah perempuan secara simbol keagamaan menempatkannya pada status kelas dua, yang tidak membutuhkan aturan-aturan berpakaian secara khusus karena tidak akan menunaikan kewajiban seperti pamangku lanang dalam menjalankan upacara.

Secara etika, pakaian pamangku istri memang perlu diatur agar tidak lagi menonjolkan pada gaya atau trand masa muda atau masa kini, walaupun umur masih muda tetapi pemikiran dan cara berpakaian sudah seperti orang dewasa. Maksudnya untuk menghilangkan kesan terjadinya mangku gaul, karena seringkali cara berpakaian pamangku istri tidak sesuai dengan 
etika atau sasana pakaian pamangku, seperti misalnya menggunakan slayer/selendang di leher pada saat menunaikan kewajiban memercikan tirtha atau sedang mendampingi pamangku lanang di Pura.

\section{e. Penggenderan Melalui Adat}

Berdasarkan perbedaan struktur sosial terjadi pula pembedaan tugas dan kewajiban diantara kerama lanang (laki-laki) dan kerama luh/istri (perempuan). Pembedaan tugas terlihat pada adanya ayahan luh dan ayahan muani. Ayahan luh yaitu tugas dan kewajiban bagi warga atau kerama perempuan untuk mengambil pekerjaan yang khusus ditujukan kepada warga masyarakat yang perempuan, seperti memasak, menyapu (membersihkan lingkungan), dan majejahitan. . Sedangkan ayahan muani ialah kewajiban dan tugas yang dilakukan hanya untuk krama/warga laki-laki, seperti gotong royong mengangkut bahan bangunan, mencakul, membersihkan selokan, mebat (mengolah bahan upacara dari binatang), memotong binatang, dan pekerjaan yang sifatnya keras.

Kaum perempuan juga tidak pernah dilibatkan dalam paruman desa adat, baik pada pasamuhan alit maupun pada pasamuan agung desa adat. Praktek pengenderan seperti ini tidak memberikan kesempatan kepada kaum perempuan untuk mengeluarkan pendapat, padahal banyak keputusan-keputusan adat yang diputuskan oleh kaum laki-laki tidak sesuai dengan keinginan dan kebutuhan untuk kaum perempuan. Seperti keputusan bahwa setiap upacara agama dilanjutkan dengan kegiatan "judi tajen" yang sering menimbulkan kekerasan dalam rumah tangga bagi kaum perempuan, dominasi laki-laki dalam memutuskan kegiatan upacara tanpa mempertimbangkan beban kerja kaum perempuan dan perekonomian masyarakat. Demikian juga pada zaman dahulu tidak diajaknya kaum perempuan untuk memilih pimpinan desa adat padahal pimpinan adalah untuk masyarakat umum. Ajaran Reg Veda X.191.2 mengajarkan kebersamaan sebagai berikut : "Sam gacchadhvam sam vadadhvam, Sam vo manamsi janatam,Deva bhagam yatha purve, Samjanana upasate.:"wahai umat manusia, anda seharusnya berjalan bersama-sama, berbicara bersama-sama dan berpikir yang sama, seperti halnya para pendahulumu bersama-sama membagi tugas-tugas mereka, begitulah anda mestinya memakai hakmu.(Titib, 1996:348).

Berdasarkan arti kitab suci Reg Veda X.191.2, bermakna tidak ada suatu perbedaan untuk menjalankan tugas-tugas kemanusiaan maupun keagamaan, karena manusia dituntut untuk mengeluarkan pendapat secara bersama-sama, karena mereka memiliki hak yang sama. Demikian pula manusia untuk menjalankan tugas-tugasnya selalu didasarkan pada hak secara sama sehingga tidak ada pembedaan hak laki-laki dan perempuan atau tugas laki-laki dan perempuan. Ajaran inipun menggariskan bahwa tidak ada perbedaan hak dan tugas pamangku lanang (laki-laki) dan pamangku istri karena semua tugas itu dapat dipertukarkan dalam kapamangkuannya. Veda menyarankan untuk berusaha memberikan kesempatan kepada wanita untuk memperoleh hak-haknya sebagai manusia yang sama dihadapan Tuhan.

\section{Kesimpulan}

Kesimpulan hasil analisis penelitian terhadap Bias Gender Kapamangkuan di desa Mengesta Kecamatan Penebel Kabupaten Tabanan, adalah sebagai berikut. Sistem penobatan pamangku di desa Mangesta Kecamatan Panebel sesuai dengan teori strukturalisme fungsional, bahwa penobatan pamangku dilakukan dengan beberapa cara diantaranya 1) dengan pemilihan, 2) berdasarkan keturunan, 3) dengan upacara Nyanjan dan 4) dengan pembagian lekesan.

Selanjutnya, faktor-faktor terjadinya ketidakadilan gender dalam hubungan kepamangkuan antara lain : 1) sistem purusa dan pradana demi swadharma agama dengan status laki-laki yang lebih utama dalam keluarga Hindu di Bali, 2) faktor dominasi laki-laki dalam kapamangkuan melalui praktik-praktik struktur sosial, budaya, ekonomi, geografis, politik, pendidikan yang menempatlan laki-laki sebagai upper class dan wanita sebagai under class; 3) faktor pendidikan kapamangkuan yang masih mengutamakan pendidikan pamangku 
lanang sebagai pemimpin upacara, mengucapkan mantra dan menggunakan gentalbajra; 4) faktor pelabelan pamangku istri lebih memiliki emosional lemah lembut, penuh kesabaran, ketrampilan seni, dengan tugas domestiknya seperti mejejahitan, membuat jajan upakara, menarikan tarian sakral, bernyanyi (mekidung) dan 5) dan faktor mitos menstruasi, berakibat pada rasa takut masyarakat terhadap aktivitas upacara agama Hindu akan terganggu kesuciannya.

Pengenderan atas kapamangkuan di Desa Mengesta melalui: 1) pemberian label pamangku istri sebagai sosialisasi wanita ke dalam polaritas gender dengan peran yang berbeda dalam kedudukan yang sama, 2) sistem pendidikan kapamangkuan yang masih memperhatikan perbedaan secara biologis, 3) sistem perkawinan kedua sebagai penggenderan pamangku dengan tidak diperkenankannya mengambil istri kedua dengan status janda yang dianggap tidak suci, 4) penggenderan melalui pakaian pamangku, yang selama ini dalam keputusan-keputusan lembaga agama tidak ada membahas mengenai pakaian pamangku istri; dan 5) penggenderan melalui adat, dengan dikenalnya kerama adat lanang dan kerama adat istri, yag mana jarang melibatkan kerama adat istri sebagai pimpinan desa adat.

\section{Daftar Pustaka}

Anonim, 1985. Awig-Awsig Desa Adat Wongaya Betan

Anonim, 2001. Pararem Desa Adat Wongaya Betan

Abdullah, Irwan.( 2006). Konstruksi dan reproduksi kebudayaan. Yogyakarta : Pustaka Pelajar

Arniati, Ida Ayu Komang. (2004). Jender dan tokoh wanita spiritual analisis penjenderan atas smerti. Program Pascasarjana IHDN Denpasar

Bawa Atmaja, I Nengah. (2004). Pelabelan seks dan gender: dekontruksi proses menjadi wanita melalui pendidikan keluarga pada masyarakat Bali. Jurnal Kajian Budaya. : Universitas Udayana,1 (2), hal. 63-82.

Bawa Atmaja, I Nengah. (2008). Gender Perspektif Budaya Bali, pada acara seminar gender dalam perspektif budaya Bali, Denpasar : PSW Unud-Biro BKPP Setda Propinsi Bali

Ibrahim, Idi Subandy. (2007). Budaya populer sebagai komunikasi dinamika popscape dan mediascape di Indonesia kontemporer. Yogyakarta : Jalasutra

Kaler, I Gusti Ketut. (1994). Butir-butir tercecer tentang adat Bali. Denpasar : Bali Agung

Kajeng,dkk. I Nyoman. (2005). Sarasamuccaya dengan teks bahasa sansekerta dan Jawa kuna. Surabaya : Paramita.

Kompilasi dokumen literer 45 tahun parisada. (N.Dana.ed). (2005). Jakarta : PHDIP

Kuper (Adam\& Jessica). (2000). Ensiklopedi illmu-Ilmu sosial. Jakarta : PT. RajaGrafindo Persada.

Putra, Mas, I.G.A. (tt). Upacara manusa yadnya. Denpasar : Institut Hindu Dharma.

Mulia, I Made. (2008). Gender dalam perspektif Sarasamuscaya. Program Pascasarjana IHDN Denpasar

Naqiyah, Najlah. (2005). Otonomi perempuan. Malang : Banyumedia.

Pudja. I Gede dan Sudharta, Tjokorda Rai. 2002). Manawa dharmaçastra (manu dharmaçastra) atau weda smrti compendium hukum Hindu. Jakarta : CV. Felita Nursatama Lestari.

Ritzer George- Douglas, J Goodman. (2005). Teori sosiologi modern. Jakarta : Prenada Media. Suhardana, K.M. Suhardana. (2006, Sarad No.10/2000) Dasar-dasar kepemangkuan suatu kajian dan bahan kajian bagi generasi mendatang. Surabaya : Paramita, 11-12.

Sumbulah, Umi. (2008). Gender dan demokrasi. Malang : Averroes Press.

Titib, I Made. (2008, April). Gender dalam perspektif agama Hindu. Makalah disampaikan pada acara seminar gender dalam perspektif budaya Bali, Denpasar : PSW Bali-Biro BKPP Setda Provinsi Bali. 
Titib, I Made. (1996). Veda sabda suci pedoman praktis kehidupan. Surabaya : Paramita 